\title{
Mineral composition of five improved varieties of cassava
}

\author{
Adeniji, T.A. ${ }^{1 *}$, Sanni, L.O. ${ }^{2}$, Barimalaa, I.S. ${ }^{1}$, and Hart, A.D. ${ }^{1}$ \\ Department of Food Science and Technology, \\ Rivers State University of Science and Technology, \\ P.M.B. 5080, Nkpolu, Port Harcourt, Nigeria. \\ ${ }^{2}$ International Institute of Tropical Agriculture, High Rainfall Station, \\ Onne, P.M.B. 008, Nchia-Eleme, Port Harcourt, Nigeria. \\ *Address for Correspondence, E-mail: tiradeniji@yahoo.com
}

ABSTRACT

\begin{abstract}
Five new cassava mosaic disease resistant (CMD) varieties released to farmers in Nigeria were evaluated for mineral composition. Results show that TME 419 differed significantly $(\mathrm{p}<0.05)$ from other varieties in calcium (900ìg/ g) and manganese (32.3ìg/g) content. The hybrid check (TMS 30572) and TMS 98/0505 were significantly different $(\mathrm{p}<0.05)$ from other varieties in magnesium (1300ìg/g) and potassium (3900ìg/g), respectively. TMS 97/2205 differed significantly $(\mathrm{p}<0.05)$ from other varieties in phosphorus (1200ìg/g) and sodium (63.7ìg/g). Data also revealed that TMS 98/0581 was significantly different $(\mathrm{p}<0.05)$ from other varieties in iron (184.2ìg/g) while TMS 98/0510 differed significantly $(\mathrm{p}<0.05)$ from other varieties both in copper (10.9ìg/g) and zinc (8.5ìg/g). Chipping and grating had no significant effect $(\mathrm{p}>0.05)$ on calcium, sodium, copper, and zinc content of cassava flour. However, treatment effect was obvious in other minerals, chipped having a significant difference $(\mathrm{p}<0.05)$ in magnesium, potassium and manganese contents compared to grated samples. Conversely, grated samples differed significantly
\end{abstract}

$(\mathrm{p}<0.05)$ in phosphorus and iron compared to chipped samples. Estimated daily recommended dietary allowances (RDA) from major minerals found in CMD varieties show that calcium, potassium, phosphorus and copper contributions to RDA ranged from $17.5-22.5 \%, 13.8-20.7 \%$, $32.1-42.9 \%$, and $127.8-302.8 \%$ in both adult males and females, respectively if $250 \mathrm{~g}$ flour is eaten daily. The highest level of magnesium contribution $(81.3 \%$ and $104.8 \%$ ) to RDA was found in TMS 30572 for adult males and females, respectively, from $250 \mathrm{~g}$ flour. TMS 98/0581 was highest in iron contribution to RDA with $575.6 \%$ and $255.8 \%$ for adult males and females, respectively, provided $250 \mathrm{~g}$ flour is eaten. TMS 98/0510 had the highest level of contribution to RDA, $19.3 \%$ for adult males, while $26.6 \%$ is accruable to adult female, provided $250 \mathrm{~g}$ flour is consumed. New cassava varieties may constitute important raw materials in the food industries based on their nutritional composition.

Key words: Minerals, nutrition, recommended daily allowance, raw materials, food industry.

\section{INTRODUCTION}

$\mathrm{C}$ assava (Manihot esculenta Crantz) is a major food crop in the humid and sub-humid parts of Africa and a major source of energy for millions of people in these regions (Asiedu, et. al. 1992). It is the most important root crop in Nigeria in terms of food security, employment creation, and income generation for crop producing households (Ugwu and Ukpabi, 2002). World production of cassava was 160 million tons of fresh roots, with 80 million tons produced in Africa, out of which 34 million tons is produced in Nigeria (FAO, 1994) and by this figure, Nigeria is the largest producer of cassava in the world. The daily per capital consumption of cassava in Nigeria contributed about one megajoule 
$(\mathrm{mJ})$ to the diet. Estimated household consumption is about 30 million metric tons, with a marketable surplus for industrial demand of about $10 \%$ of total production (Nwachukwu, 2005). The adaptation of cassava to the food and farming systems and multiplicity of uses makes it indispensable to food security. Cassava is a cheap source of carbohydrate from nutritional point of view. The roots of currently available varieties are relatively low in protein, although in Central Africa, substantial amounts of protein are derived from cassava leave, which are a popular vegetable (Berry, 1993).

The major uses of cassava in Nigeria (Philip, et $a l ., 2005)$ include flour, which involves several unit operations, resulting in flour of different properties, which are used for various purposes. Other products include gari, creamy-white, granular flour with a slightly fermented flavour and slightly sour taste. Fresh roots may also be boiled and pounded to obtain pounded $f u f u$, which is popular in Ghana, and to some extent in Nigeria and Cameroon (Hahn, 1997). Fresh cassava roots also finds considerable use as a feed for livestock such as goat, sheep, cattle, and particularly pigs (Ihekoronye and Ngoddy, 1985). Nwosu (2005) identified some of the industrial uses of cassava including ethanol production, livestock feeds, confectioneries, monosodium glutamate processing, sweeteners, glues, textiles and pharmaceuticals.

The International Institute of Tropical Agriculture (IITA) had developed several varieties of cassava mosaic disease resistant cultivars. New varieties are being currently disseminated in Nigeria and many parts of West and Central Africa (WCA) and East and Southern Africa (ESA) to improve agricultural productivity, rural income and generate raw materials for local industries. The mineral composition of five top varieties of CMD released cultivars was therefore investigated to enhance delivery, utilization and industrial potential.

\section{MATERIALS AND METHODS}

Five new released varieties of cassava (98/ 0505, TME 419, 97/2205, 98/0581, and 98/0510, including the reference, TMS 30572) were investigated. Tuberous cassava roots were harvested one year after planting from the experimental station of the International Institute of Tropical Agriculture, High Rainfall Station, Onne agro ecology, located on Latitude $04^{\circ} 43^{\prime} \mathrm{N}$, Longitude $07^{\circ} 01^{\prime} \mathrm{E}$ and $10 \mathrm{~m}$ Altitude, near Port Harcourt, Nigeria. Root samples were peeled manually with the aid of stainless steel kitchen knife. Some aliquots were chipped into small pieces, while some were grated prior to dehydration. Samples were placed in petri dish and covered with filter paper to avoid contamination, and transferred carefully into Forced-Air Sanyo Gallenkamp Moisture Extraction Oven and dried at $65^{\circ} \mathrm{C}$ for about 48 hours and milled with the aid of stainless Kenwood Chef Warring Blender, Model KM001 series. Mineral analysis was performed using the procedure described by Allen et al., (1984). Daily recommended dietary allowances (RDA) from major minerals found in CMD varieties were estimated with reference to Institute of Medicine, National Academy of Sciences (2002) tables of RDA. All mineral elements investigated were determined spectrophotometrically on the Buck Scientific Atomic Absorption/Emission Spectrophotometer 205 in the Plant Anatomy and Physiology Research Laboratory, Faculty of Science, University of Port Harcourt, Herbarium, Port Harcourt, Nigeria.

\section{Data Analysis}

The data generated were analysed using Statistical Analysis Systems version 9.1 SAS (2003) software package. Significance of treatment means was tested at 5\% probability level using Duncan's New Multiple Range Test (DNMRT).

\section{RESULTS AND DISCUSSION}

Mineral profile of CMD varieties is presented in Table 1, which shows a significant difference $(p<0.05)$ between TME 419 and other varieties in 
calcium (900ìg/g) and manganese (32.3ìg/g) content. The range of calcium $(700-900 \mu \mathrm{g} / \mathrm{g})$ levels found in new CMD varieties is higher than $330 \mu \mathrm{g} / \mathrm{g}$ earlier reported in cassava root (Ihekoronye and Ngoddy, 1985). The physiological roles of minerals in human diet have been widely reported (Ihekoronye and Ngoddy, 1985; Okaka et al., 1992; Onigbinde, 2001). The hybrid check, TMS 30572 and TMS 98/0505 were significantly different $(\mathrm{p}<0.05)$ from other varieties in magnesium (1300ìg/g) and potassium (3900ìg/g), respectively. TMS 97/2205 differed significantly $(\mathrm{p}<0.05)$ from all other varieties in phosphorus (1200ìg/g) and sodium (63.7ìg/g) content. TMS 98/0581 was significantly different $(\mathrm{p}<0.05)$ fromother varieties in iron $(184.2 \mathrm{ig} / \mathrm{g})$ while TMS 98/0510 differed significantly $(\mathrm{p}<0.05)$ from other varieties both in copper (10.9ìg/g) and zinc $(8.5 \grave{i g} / \mathrm{g})$. The levels of iron found in new CMD varieties were much higher than $7 \mu \mathrm{g} / \mathrm{g}$ reported in fresh cassava roots (FAO, 1998) and $64 \mu \mathrm{g} / \mathrm{g}$ reported in sweet potato (Ihekoronye and Ngoddy, 1985). Moreover, this new data surpassed $1.06 \mathrm{mg} /$ $100 \mathrm{~g}$ of iron obtained in raw green plantain (Ahenkora, et. al., 1996) and 0.2-0.3mg/100g values obtained in flours of two sweet potato varieties (Onuh, et al., 2004). The same trend was observed for zinc, when compared to a meager level of $0.26 \mathrm{mg} /$ 100g obtained by Ahenkora et al. (1996) in Apantu pa plantain in Ghana. Chipping and grating had no significant effect $(\mathrm{p}>0.05)$ on calcium, sodium, copper, and zinc content of cassava flour (Table 3 ).
Chipped samples had a significant difference $(p<0.05)$ in magnesium, potassium and manganese contents compared to grated samples. Conversely, grated samples differed significantly $(\mathrm{p}<0.05)$ in phosphorus and iron compared to chipped samples. Ebuehi (2005) reported significant losses in various minerals including calcium, magnesium, phosphorus, iron, sodium and chloride ions identified in the roots and raw leaves of cassava as a result of boiling. Boiling and frying has also been implicated in losses of certain micronutrient in plantain including iron, copper and zinc (Ahenkora, et al., 1996). Daily recommended dietary allowances from major minerals found in CMD varieties were estimated (Table 3). Results show that calcium, potassium, phosphorus and copper contribution to RDA ranged from $17.5-22.5 \%, 13.8-20.7 \%, 32.1-42.9 \%$, and $127.8-302.8 \%$ in both adult males and females, respectively if $250 \mathrm{~g}$ flour is eaten daily. The highest level of magnesium contribution (81.3\% and $104.8 \%$ ) to RDA was found in TMS 30572 for adult males and females, respectively, from $250 \mathrm{~g}$ flour. TMS 98/0581 was highest in iron contribution to RDA with $575.6 \%$ and $255.8 \%$ for adult males and females, respectively. The trend with zinc follows a different pattern, with TMS 98/0510 having the highest level of contribution to RDA, $19.3 \%$ for adult males, while $26.6 \%$ is accruable to adult female, provided that $250 \mathrm{~g}$ flour is consumed. Increased production and utilization of new cassava varieties may contribute to offset micronutrient deficiencies prevailing in Africa. 
Table 1. Mineral composition of cassava mosaic disease resistant (CMD) varieties

\begin{tabular}{|c|c|c|c|c|c|c|c|c|c|}
\hline Cultivar & $\mathrm{Ca}$ & Mg & $\mathbf{K}$ & $\mathbf{P}$ & $\mathrm{Na}$ & Mn & $\mathbf{F e}$ & $\mathbf{C u}$ & $Z_{n}$ \\
\hline \multicolumn{10}{|c|}{$\mu \mathrm{g} / \mathrm{g}$} \\
\hline TMS 97/2205 & $800^{\mathrm{b}}$ & $800^{c}$ & $2900^{\circ}$ & $1200^{\mathrm{a}}$ & $63.7^{\mathrm{a}}$ & $28.1^{\mathrm{d}}$ & $163.5^{\mathrm{d}}$ & $6.3^{\mathrm{c}}$ & $8.0^{c}$ \\
\hline TMS 98/0505 & $700^{c}$ & $700^{d}$ & $3900^{a}$ & $1000^{b}$ & $50.3^{e}$ & $28.2^{\mathrm{c}}$ & $184.0^{b}$ & $4.6^{\mathrm{d}}$ & $6.0^{\mathrm{e}}$ \\
\hline TMS 98/0510 & $700^{c}$ & $900^{b}$ & $3500^{b}$ & $1000^{b}$ & $46.9^{f}$ & $24.5^{\mathrm{e}}$ & $117.3^{\mathrm{f}}$ & $10.9^{\mathrm{a}}$ & $8.5^{\mathrm{a}}$ \\
\hline TMS 98/0581 & $800^{b}$ & $700^{d}$ & $3100^{c}$ & $1200^{\mathrm{a}}$ & $50.4^{\mathrm{d}}$ & $28.2^{\mathrm{c}}$ & $184.2^{\mathrm{a}}$ & $6.3^{c}$ & $5.6^{\mathrm{f}}$ \\
\hline TME419 & $900^{a}$ & $700^{d}$ & $2600^{f}$ & $1000^{b}$ & $58.5^{\mathrm{b}}$ & $32.3^{\mathrm{a}}$ & $168.5^{\mathrm{c}}$ & $8.1^{\mathrm{b}}$ & $7.6^{\mathrm{d}}$ \\
\hline TMS 30572 & $800^{b}$ & $1300^{\mathrm{a}}$ & $3000^{d}$ & $900^{c}$ & $55.1^{\mathrm{c}}$ & $31.9^{b}$ & $123.1^{\mathrm{e}}$ & $6.3^{c}$ & $8.3^{\mathrm{b}}$ \\
\hline
\end{tabular}

Values in the same column with different letters are significantly different at $p<0.05$.

Table 2. Effect of processing on mineral composition of cassava mosaic disease resistant varieties

\begin{tabular}{|c|c|c|c|c|c|c|c|c|c|}
\hline & Ca & Mg & $\mathbf{K}$ & $\mathbf{P}$ & $\mathbf{N a}$ & Mn & $\mathrm{Cu}$ & $\mathrm{Fe}$ & $\mathbf{Z n}$ \\
\hline \multicolumn{10}{|l|}{ Treatment } \\
\hline Chipped & $800^{\mathrm{a}}$ & $1040^{a}$ & $3920^{a}$ & $720^{b}$ & $53.53^{\mathrm{a}}$ & $30.80^{\mathrm{a}}$ & $7.28^{\mathrm{a}}$ & $105.64^{\mathrm{b}}$ & $6.44^{\mathrm{a}}$ \\
\hline Grated & $783^{a}$ & $850^{\mathrm{b}}$ & $3170^{\mathrm{b}}$ & $1050^{a}$ & $54.15^{\mathrm{a}}$ & $28.87^{\mathrm{b}}$ & $7.08^{\mathrm{a}}$ & $156.77^{a}$ & $7.33^{\mathrm{a}}$ \\
\hline
\end{tabular}

Chipped=Fresh cassava roots were chipped after peeling prior to dehydration, Grated $=$ Fresh cassava roots were grated after peeling prior to dehydration.

Values in the same column with different letters are significantly different at $p<0.05$. 
Table 3. Mineral composition of cassava mosaic disease resistant varieties to daily recommended dietary allowance

\begin{tabular}{|c|c|c|c|c|c|c|c|}
\hline \multirow[b]{3}{*}{ Cultivar } & \multirow[b]{3}{*}{$\mathbf{C a}$} & \multicolumn{6}{|c|}{$\%$ Minerals from daily consumption of $250 \mathrm{~g}$ flour } \\
\hline & & \multicolumn{3}{|c|}{ Adult Male/Female } & \multirow[b]{2}{*}{$\mathrm{Cu}$} & \multirow[b]{2}{*}{$\mathbf{F e}$} & \multirow[b]{2}{*}{$\mathbf{Z n}$} \\
\hline & & Mg & $\mathbf{K}$ & $\mathbf{P}$ & & & \\
\hline TMS 97/2205 & 20/20 & $50 / 64.5$ & $15.4 / 15.4$ & $42.9 / 42.9$ & $175 / 175$ & $510.9 / 227.1$ & $18.2 / 25$ \\
\hline TMS 98/0505 & $17.5 / 17.5$ & $43.8 / 56.5$ & $20.7 / 20.7$ & $35.7 / 35.7$ & $127.8 / 127.8$ & $575 / 255.6$ & $13.6 / 18.8$ \\
\hline TMS 98/0510 & $17.5 / 17.5$ & $56.3 / 72.6$ & $18.6 / 18.6$ & $35.7 / 35.7$ & $302.8 / 302.8$ & $366.6 / 162.9$ & $19.3 / 26.6$ \\
\hline TMS 98/0581 & $20 / 20$ & $43.8 / 56.5$ & $16.5 / 16.5$ & $42.9 / 42.9$ & $175 / 175$ & $575.6 / 255.8$ & $12.7 / 17.5$ \\
\hline TME419 & $22.5 / 22.5$ & $43.8 / 56.5$ & $13.8 / 13.8$ & $35.7 / 35.7$ & $225 / 225$ & $526.6 / 234.0$ & $17.3 / 23.8$ \\
\hline TMS 30572 & $20 / 20$ & $81.3 / 104.8$ & $15.9 / 15.9$ & $32.1 / 32.1$ & $175 / 175$ & $384.7 / 170.9$ & $18.9 / 25.9$ \\
\hline
\end{tabular}

RDA for adult males and females are 1000mg Ca each, 400mg and 310mg Mg, respectively, $4.7 \mathrm{~g} \mathrm{~K}$ each, 700mg P each, 900ig/g Cu each, 8mg and $18 \mathrm{mg} \mathrm{Fe}$, respectively and $11 \mathrm{mg}$ and $8 \mathrm{mg} \mathrm{Zn}$ (Institute of Medicine, National Academy of Sciences, 2002).

Estimated values were obtained from data on mineral composition of CMD varieties in Table 1.

\section{REFERENCES}

Ahenkora, K., Kyei, M.A., Marfo, E.K, Banful, B. (1996). Nutritional composition of False Horn Apantu pa plantain during ripening and processing. African Crop Science Journal, 4 (2): 243-247.

Allen, S.E., Grimshaw, H.M, Parkinson, J.A. and Quarmby, C. (1984). Chemical analysis of ecological materials. Edited by S.E. Allen. Blackwell Scientific Publications, Oxford London, Edinburgh, Melbourne, 565pp.

Asiedu, R., Ng, S.Y.C., Vuylsteke, D., Terauchi, R., and Hahn, S.K. (1992). Analysis of the need for biotechnology research on cassava, yam, and plantain. In: Thottappilly, G., Monti, L., Mohan Raj, D.R., and Moore, A.W. (eds.). Biotechnology: Enhancing research on tropical crops in Africa. CTA/ IITAco-publication. IITA, Ibadan, Nigeria, 376pp.
Berry, S.S. (1993). Socio-economic aspects of cassava cultivation and use in Africa: implication for the development of appropriate technology. COSCA Working Paper No. 8, Collaborative Study on Cassava in Africa, International Institute of Tropical Agriculture, Ibadan.

Ebuehi, O.A.T., Babalola O and Ahmed, Z (2005). Phytochemical, nutritive and anti-nutritive composition of cassava (Manihot esculenta L) tubers and leaves. Nigerian Food Journal, 23: 4046.

FAO (1994). FAO Production Year Book, Food and Agricultural Organisation of the United Nations, Rome.

FAO (1998). The Food Composition Tables for use in Africa. FAO and US Department of Health and Welfare. 
Hahn, S.K. (1997). Traditional processing and utilization of cassava in Africa. IITA Research Guide 41. Training Program, International Institute of Tropical Agriculture (IITA), Ibadan, Nigeria, Fourth Edition, p 42.

Ihekoronye, A.I. and Ngoddy, P.O. (1985). Integrated Food Science and Technology for the Tropics. Macmillan Publishers Ltd., London and Basingstoke, p 386.

Institute of Medicine, National Academy of Sciences (2002). Dietary Reference Intakes for Energy, Carbohydrate, Fiber, Fat, Fatty Acids, Cholesterol, Protein, and Amino Acids, Food and Nutrition Board, Washington D.C., National Academic Press.

Nwachukwu, E.O. (2005). Cassava Processing and Equipment Assessment: Tool for Poverty Alleviation. Presented at State Workshop on Empowering the Grassroots Through Promotion of Commercial Cassava Production and Processing, October 1112, Owerri, Nigeria.

Nwosu, O.S.U. (2005). Cassava Cultivation, Varieties Available and Land Preparation. Presented at State Workshop on Empowering the Grassroots Through Promotion of Commercial Cassava Production and Processing, October 11-12, Owerri, Nigeria.
Okaka, J.C., Akobundu, E.N.T., and Okaka, A.N.C. (1992). Human Nutrition: an integrated approach, Enugu State University of Science and Technology, Enugu, Nigeria.

Onigbinde, A.O. (2001). Human Nutrition (Biochemical Integration). Ilupeju Publishers Ltd., Benin City, Nigeria, p300.

Onuh, J.O., Akpapunam, M.A., and Iwe, M.O. (2004). Comparative studies of the physicochemical properties of two local varieties of sweet potato flours. Nigerian Food Journal, 2: 141-146.

Philip, T., D. Taylor, L. Sanni, R. Okechukwu, C. Ezedinma, M. Akoroda, J. Lemchi, P. Ilona, F. Ogbe, E. Okoro and A.G.O. Dixon (2005). The Nigerian cassava industry: Statistical handbook, International Institute of Tropical Agriculture (IITA), Ibadan, p 94.

SAS (2003). Statistical Analysis Software (SAS) Systems for Windows, SAS Institute Inc., Cary, NC, USA.

Ugwu, B.O. and Ukpabi, U.J. (2002). Potential of soy-cassava flour processing to sustain increasing cassava production in Nigeria. Outlook on Agriculture, Vol. 31, No. 2, p. 129-133. 